\title{
An analysis of Methylenetetrahydrofolate reductase and Glutathione S-transferase omega-I genes as modifiers of the cerebral response to ischemia
}

\author{
Leema Reddy Peddareddygari ${ }^{1}$, Ana Virginia Dutra ${ }^{1}$, Mark A Levenstien², \\ Souvik Sen ${ }^{3}$ and Raji P Grewal*1
}

\begin{abstract}
Address: ${ }^{1}$ New Jersey Neuroscience Institute at JFK Medical Center, 65 James Street, Edison, New Jersey, USA, ${ }^{2}$ Program in Cancer Biology and Genetics, Memorial Sloan-Kettering Cancer Center, 1275 York Avenue, New York, New York, USA and ${ }^{3}$ UNC Hospital Stroke Center, 7003 A Neuroscience Hospital, CB 7025, Chapel Hill, North Carolina, USA

Email: Leema Reddy Peddareddygari - lrpeddareddygari@solarishs.org; Ana Virginia Dutra - dutracla@mskcc.org; Mark A Levenstien - levenstm@mskcc.org; Souvik Sen - SenS@neurology.unc.edu; Raji P Grewal* - rgrewal@solarishs.org

* Corresponding author
\end{abstract}

Published: 22 July 2009

BMC Neurology 2009, 9:37 doi:10.1 186/147/-2377-9-37
Received: 4 May 2009

Accepted: 22 July 2009

This article is available from: http://www.biomedcentral.com/I47I-2377/9/37

(c) 2009 Peddareddygari et al; licensee BioMed Central Ltd.

This is an Open Access article distributed under the terms of the Creative Commons Attribution License (http://creativecommons.org/licenses/by/2.0), which permits unrestricted use, distribution, and reproduction in any medium, provided the original work is properly cited.

\begin{abstract}
Background: Cerebral ischemia involves a series of reactions which ultimately influence the final volume of a brain infarction. We hypothesize that polymorphisms in genes encoding proteins involved in these reactions could act as modifiers of the cerebral response to ischemia and impact the resultant stroke volume. The final volume of a cerebral infarct is important as it correlates with the morbidity and mortality associated with non-lacunar ischemic strokes.
\end{abstract}

Methods: The proteins encoded by the methylenetetrahydrofolate reductase (MTHFR) and glutathione S-transferase omega-I (GSTO-I) genes are, through oxidative mechanisms, key participants in the cerebral response to ischemia. On the basis of these biological activities, they were selected as candidate genes for further investigation. We analyzed the C677T polymorphism in the MTHFR gene and the C4I9A polymorphism in the GSTO-I gene in 128 patients with nonlacunar ischemic strokes.

Results: We found no significant association of either the MTHFR $(p=0.72)$ or GSTO-I $(p=0.58)$ polymorphisms with cerebral infarct volume.

Conclusion: Our study shows no major gene effect of either the MTHFR or GSTO-I genes as a modifier of ischemic stroke volume. However, given the relatively small sample size, a minor gene effect is not excluded by this investigation.

\section{Background}

In the United States, after cardiovascular disease and cancer, stroke is the third leading cause of death. However, it is the leading cause of morbidity resulting in about 4 million stroke survivors each year [1]. Although there are epidemiological differences in various ethnic groups, the majority of these strokes are ischemic rather than hemorrhagic in nature. There are a number of well established risk factors for the development of ischemic stroke including diabetes mellitus, atrial fibrillation, hypertension and age [2]. Once an ischemic stroke occurs, in spite of intense research efforts, little progress has been made in the dis- 
covery or development of effective neuroprotective agents.

While there are recent research efforts investigating susceptibility genes for ischemic stroke, there are few investigations of the genetics of the cerebral response to ischemia $[3,4]$. Studies of induced strokes in transgenic animals indicate that manipulation of certain genes can influence the resultant volume $[5,6]$. We hypothesize that there is variability in the cerebral response to ischemia that is mediated by polymorphisms in genes encoding proteins which participate in this response. Polymorphisms in these genes could enhance or diminish endogenous neuroprotective mechanisms and ultimately impact the volume of an ischemic stroke. This has clinical significance because, in general, the volume of a stroke correlates with severity and the resultant degree of disability of the patient $[7,8]$.

It has been established that cerebral ischemic injury results in a core of necrotic tissue surrounded by a penumbra of tissue in which neurons are functionally inactive but still potentially viable [9]. The development of this ischemic penumbra is limited in time by a cascade of reactions in response to the initial ischemia followed by subsequent reperfusion. Reperfusion occurring shortly after ischemia reduces infarct volume, but at a later period may exacerbate ischemic injury [10]. It has been suggested that reperfusion increases reactive oxygen species (ROS) production which can have further deleterious consequences. Neuronal cell exposure to these ROS, which include nitric oxide, superoxide ions and hydroxyl radicals, can result in oxidative deoxyribonucleic acid (DNA) damage [11-14].

Methylenetetrahydrofolate reductase (MTHFR) and Glutathione S-transferase omega-1(GSTO-1) are two genes that are key participants in the metabolic pathways regulating oxidative stress in the brain (Fig 1). The C677T polymorphism (NCBI SNP cluster ID rs\# 1801133) in MTHFR gene results in an alanine-to-valine (A222V) substitution which in turn causes a reduction in enzyme activity and subsequent elevation of plasma homocysteine $[15,16]$. Hyperhomocysteinemia (HHcy) has been reported as an independent risk factor for stroke but may also influence ischemic stroke volume. A study of the cerebral volume and induced stroke following middle cerebral artery occlusion in mice showed that HHcy was associated with increased oxidative damage and larger ischemic lesion [17-19]. The homocysteine (Hcy) dependent trans-sulfuration pathway is responsible for maintenance of the intracellular glutathione pool and regulation of this pathway under oxidative stress (Fig 1). GSTO-1 is member of Phase II enzymes that catalyze glutathione-dependent antioxidant pathways (Fig 1). Furthermore GSTO-1 modulates rynodyne receptors thereby protecting cells against $\mathrm{Ca}^{2+}$ induced apoptosis and inhibition of the posttranslational processing of pro-inflammatory cytokine interleukin-1 $\beta \quad[20,21]$. The C419A (NCBI SNP cluster ID, rs 4925) polymorphism in GSTO1 gene has been reported to be involved in stroke [22]. The C419A polymorphism results in amino acid alteration alanine-to-aspartate; this change in the protein sequence reduces enzyme activity and therefore could influence tissue susceptibility to oxidative stress [23].

Given the key roles of the products of these two genes in the cerebral response to ischemia, they are candidate genes which warrant further investigation. We hypothesized that the MTHFR C677T and GSTO-1 C419A polymorphisms may modify the response of the brain to cerebral ischemia and ultimately impact the final stroke volume. To test our hypothesis we studied the relationship of these polymorphisms with infarct volume measured in patients who have suffered an ischemic stroke.

\section{Methods}

\section{Human subjects}

We studied 128 patients admitted to the stroke unit at John F. Kennedy Medical Center, Edison, New Jersey with non-lacunar ischemic infarcts. The strokes were categorized according to the Trial of ORG 10172 in Acute Stroke Treatment (TOAST) [24]. Among these patients, applying the TOAST classification, the etiology of the non-lacunar ischemic strokes included 37 large artery atherothrombosis, 37 cardioembolic, 49 unknown and 5 others. In the majority of patients $(79 \%)$, diffusion-weighted magnetic resonance imaging scans were available for review; alternatively, cerebral computed tomography scans (21\%) were used to measure stroke volume. The stroke volume was obtained by averaging the calculated values from direct measurements of the cerebral images by two examiners as previously described [25]. Informed consents were obtained from the patients or their proxies and study was conducted according to protocols and methods approved by the local Institutional Review Board.

\section{Genotyping}

Genomic DNA was isolated from blood samples (Puregene Systems, Gentra). The MTHFR polymorphisms were genotyped as previously described [15]. Briefly, the primer pairs used were F: 5'-TGAAGGAGAAGGTGTCTGCGGGA-3' and R: 5'-AGGACGGTGCGGTGAGAGTG-3'. The C677T polymorphism creates a restriction site for Hinf I, so the digestion of the polymerase chain reaction (PCR) products of the mutant allele generates two fragments (175 and $23 \mathrm{bp}$ ). The digested products were resolved by gel electrophoresis ( $6 \%$ polyacrylamide gel) and the allele frequency was obtained by direct gene counting. The genotypes obtained with this method were confirmed by direct sequencing. 


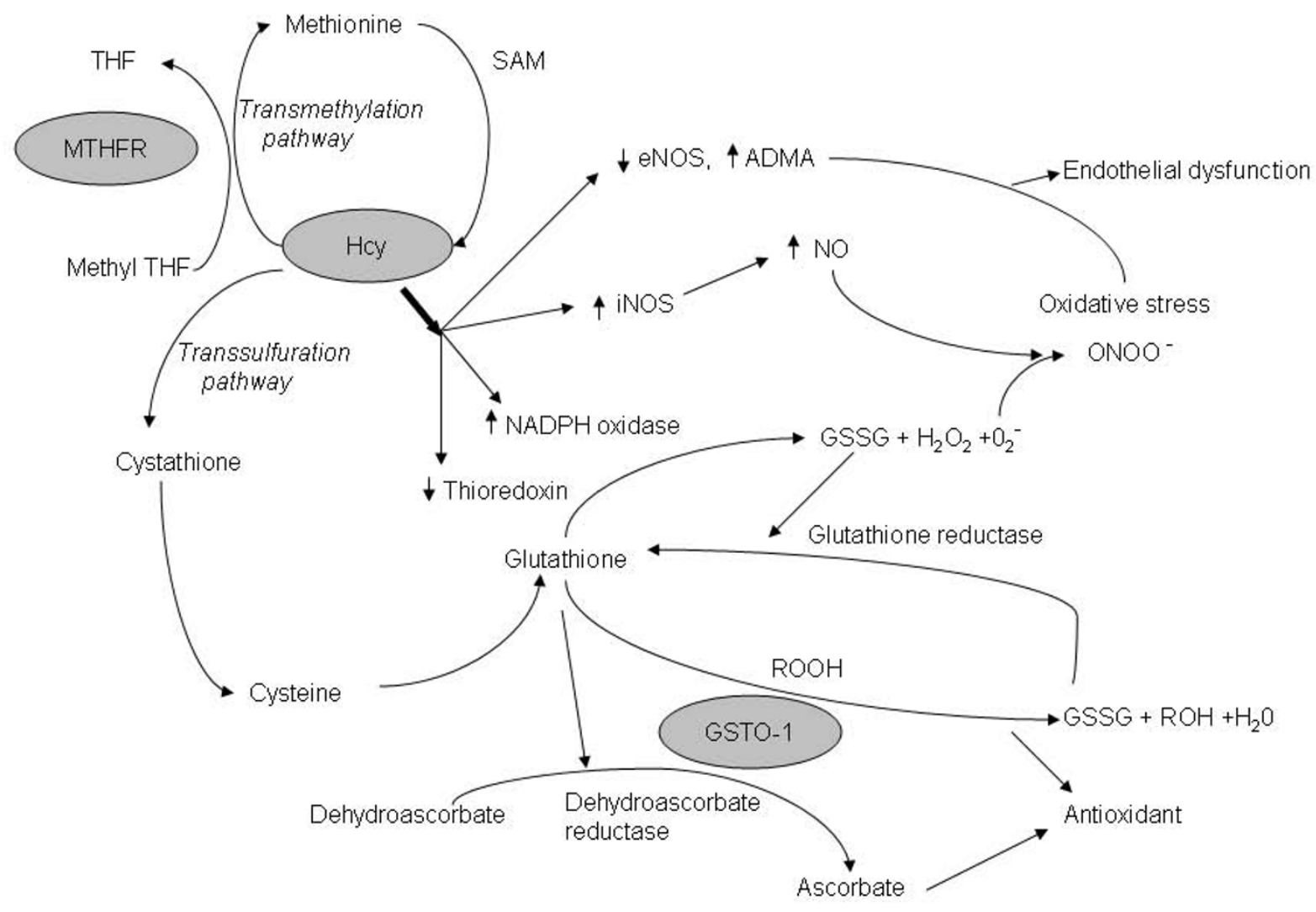

Figure I

The metabolic pathways regulating oxidative stress. Abbreviations: MTHFR- Methylenetetrahydrofolate reductase, THF- tetrahydro folate, Hcy- Homocysteine, SAM- S-Adenosyl methionine, eNOS-endothelial nitric oxide synthase, iNOSinducible nitric oxide synthase, ADMA- asymmetric dimethylarginine, $\mathrm{NO}$ - nitric oxide, $\mathrm{O}_{2}^{-}-$superoxide radical, ONOO- peroxinitrite, $\mathrm{H}_{2} \mathrm{O}_{2}$-hydrogen peroxide, NADPH - nicotinamide adenine dinucleotide phosphate, GSTO-I- Glutathione S-transferase omega-I, GSSG -glutathione disulfide, $\mathrm{ROOH}$ - reduced hydroperoxides, $\mathrm{ROH}$ - alcohol, $\mathrm{H}_{2} \mathrm{O}$ - water.

The GSTO-1 polymorphism was detected after PCR amplication using following primer pairs F: 5'-TGTCTAGGTGCCATCCTTGGT-3' and R: 5'-AAGTGACTTGGAAAGTG GGAA-3'. PCR was carried out in a final volume of $50 \mu \mathrm{l}$ with $40 \mathrm{ng}$ of DNA, $600 \mu \mathrm{M}$ dNTP and $2.5 \mathrm{U}$ Amplitaq gold polymerase. Thermal cycling consisted of initial activation $\left(95^{\circ} \mathrm{C}\right.$ for $\left.7 \mathrm{~min}\right)$ followed by 35 cycles of denaturation $\left(95^{\circ} \mathrm{C}, 30 \mathrm{~s}\right)$, annealing $\left(56^{\circ} \mathrm{C}, 30 \mathrm{~s}\right)$, and extension $\left(72^{\circ} \mathrm{C}, 30 \mathrm{~s}\right)$ and a final extention at $72^{\circ} \mathrm{C}$ for $7 \mathrm{~min}$. PCR products were digested with restriction enzyme Cac8I at $37^{\circ} \mathrm{C}$ overnight and the digested products were resolved by gel electrophoresis ( $6 \%$ polyacrylamide gel). The digestion generates two fragments (147 bp and $60 \mathrm{bp}$ ) corresponding to $\mathrm{C}$ (restriction site present) and a single 207 bp product corresponding to the A allele (restriction site absent). The allele frequency was obtained by direct gene counting. The genotypes obtained with this method were confirmed by direct sequencing.

\section{Results}

The clinical and demographic data of the study group is presented in table 1. The genotypes of the MTHFR C677T and GSTO-1 C419A polymorphisms are presented in table 2 . The observed numbers of each genotype was compared with those expected under Hardy-Weinberg equilibrium (HWE) by using a web-based program http:// ihg.gsf.de/cgi-bin/hw/hwa1.pl. No significant deviation from HWE was observed. The mean Hcy levels corresponding to each genotype is presented in the table 3 . Although the mean Hcy level is higher in the group with MTHFR TT genotype, it is not statistically significant. To detect the effect of the MTHFR C677T and GSTO-1 C419A polymorphisms on stroke volume ANOVA and generalized linear model analysis was done. The mean stroke volume was $71.37 \mathrm{~cm}^{3}$ (SD $90.1 \mathrm{~cm}^{3}$ ). There was no significant influence of the MTHFR ( $\mathrm{p}=0.72)$ or GSTO-1 ( $\mathrm{p}=0.58)$ polymorphisms on the stroke volume. The analysis was also performed for Caucasian population 
Table I: Patient characteristics.

\begin{tabular}{lc}
\hline Demographic factors & \\
\hline Female $\mathrm{n}(\%)$ & $69(52.4)$ \\
Age, y mean (S.Da) & $70.7(13.1)$ \\
Ethnicity $\mathrm{n}(\%)$ & \\
Caucasians & $86(67.2)$ \\
African Americans & $9(7.0)$ \\
Hispanics & $13(10.2)$ \\
Others ${ }^{b}$ & $20(15.6)$ \\
Co morbidities ${ }^{\mathrm{c}} \mathrm{n}(\%)$ & \\
Hypertension & $105(82.0)$ \\
Diabetes & $55(43.0)$ \\
Atrial fibrillation & $37(28.9)$ \\
Carotid stenosis $=70 \%$ & $41(32.3)$ \\
TOAST Classification ${ }^{\mathrm{d}} \mathrm{n}(\%)$ & \\
Large artery atherosclerosis & $37(28.9)$ \\
Cardiembolism & $37(28.9)$ \\
Unknown & $49(38.3)$ \\
Others & $5(3.9)$ \\
\hline
\end{tabular}

The clinical and demographic data of the study group.

a S.D = Standard deviation.

$\mathrm{b}$ Include Asians and other ethnic groups.

c Other factors studied include Coronary artery disease, Peripheral vascular disease, Lipid profile, Homocysteine levels.

d TOAST = Trial of Org 10172 in Acute Stroke Treatment.

e Include stroke of undetermined etiology or those due to two or more causes.

alone which represented $67.2 \%$ of the study population. However no significant effect of either MTHFR $(\mathrm{p}=0.41)$ or GSTO-1 ( $\mathrm{p}=0.83$ ) polymorphisms on the size of stroke was detected.

\section{Discussion}

Our analysis did not show a major gene effect of either the MTHFR C677T polymorphism or GSTO-1 C419A polymorphism on the volume of the ischemic infarct. However, minor genetic effects are not excluded by this study. It is possible that such minor gene effects may be additive and particular combinations of polymorphisms from different genes may confer neuroprotection. These minor gene effects could be detected by studying a much larger sample size.

In addition to investigating genes involved in the response of the brain following ischemia, there are other variables that could confound the analysis. For example, due to our relatively small sample size we did not separate
Table 2: Genotype and stroke volume data.

\begin{tabular}{lllc}
\hline & Genotype & $\mathrm{N}$ & Mean stroke volume $\left(\mathrm{cm}^{3}\right)$ \\
\hline \multirow{2}{*}{ C677T } & CC & 49 & 59.5 \\
& CT & 60 & 84.6 \\
& TT & 18 & 61.5 \\
C419A & CC & 55 & 72.7 \\
& AC & 54 & 74.0 \\
& AA & 14 & 63.9 \\
\hline
\end{tabular}

and analyze the volumes of strokes occurring in a particular vascular distribution. To enhance the detection of minor gene effects, future studies could focus only upon middle cerebral artery stroke. In this study, again due to small sample size, we did not limit our analysis to those strokes of a particular etiology but rather focused upon the entire group. There may to be biological/genetic differences in the cerebral response to ischemia in cardioembolic stroke compared with large artery atherosclerosis.

\section{Conclusion}

In spite of the negative results, our study demonstrates the feasibility of studying the potential role of genes which participate in the cerebral response to ischemia and ultimately influence stroke volume. Many of the difficulties of any such investigation can be overcome by studying a larger sample size of patients. These studies could provide insight into endogenous neuroprotective mechanisms and facilitate the development of more effective therapies.

\section{Abbreviations}

MTHFR: Methylenetetrahydrofolate reductase; GSTO-1: Glutathione S-transferase omega-1; ROS: Reactive oxygen species; DNA: Deoxyribonucleic acid; HHcy: Hyperhomocysteinemia; Hcy: Homocysteine; TOAST: Trial of ORG 10172 in Acute Stroke Treatment; PCR: Polymerase chain reaction; HWE: Hardy-Weinberg equilibrium.

\section{Competing interests}

The authors declare that they have no competing interests.

\section{Authors' contributions}

LRP carried out the molecular genetic study and analysis and drafted the manuscript. AVD assisted with the molecular genetic study. ML performed the statistical analysis.

Table 3: Genotype and homocysteine data

\begin{tabular}{llll}
\hline & Genotype & N & Mean plasma homocysteine $(\mu \mathrm{mol} / \mathrm{L})$ \\
\hline \multirow{2}{*}{ MTHFR C677T } & CC & 38 & 10.7 \\
& CT & 44 & 10.8 \\
GSTO-I C419A & TT & 14 & 11.7 \\
& CC & 43 & 10.7 \\
& AC & 40 & 10.7 \\
& AA & 12 & 10.3
\end{tabular}


SS participated in the design and finalizing the manuscript. RG participated in the design, coordination of the study and finalized the manuscript. The manuscript is read and approved by all the authors.

\section{Acknowledgements}

This study was funded by intramural funds from the New Jersey Neuroscience Institute and the Neurogenetics Foundation. We are grateful to all the Hematology laboratory personnel at JFK Medical Center, Edison, NJ for their help in collection of blood samples for this study. We also thank Dr. G.K. Dhaliwal for criticism and comments regarding this manuscript.

\section{References}

I. Rosamond W, Flagel K, Friday G, Furie K, Go A, Greenlund K, Haase N, Ho M, Howard V, Kissela B, Kittner S, Lloyd-Jones D, McDermott M, Meigs J, Moy C, Nichol G, O'Donnell C], Roger V, Rumsfeld J, Sorlie P, Steinburger J, Thom T, Wasserthiel-Smoller S, Hong Y, American Heart Association Statistics Committee and Stroke Statistics Subcommittee: Heart disease and stroke statistics-2007 update: a report from the American Heart Association Statistics Committee and Stroke Statistics Subcommittee. Circulation 2007, I I5(5):e69-|7|.

2. Goldstein LB, Adams R, Becker K, Furberg CD, Gorelick PB, Hademenos G, Hill M, Howard G, Howard VJ, Jacobs B, Levine SR, Mosca L, Sacco RL, Sherman DG, Wolf PA, del Zoppo GJ: Primary prevention of ischemic stroke: A statement for healthcare professionals from the Stroke Council of the American Heart Association. Stroke 200I, 32(1):280-99.

3. Dutra AV, Lin HF, Juo SH, Boyadjis M, Moussouttas M, Reddy PL, Grewal RP: Analysis of the endothelial nitric oxide synthase gene as a modifier of the cerebral response to ischemia. I Stroke Cerebrovasc Dis 2006, I 5(3): | 28-3|.

4. Dutra AV, Lin HF, Juo SH, Mohrenweiser H, Sen S, Grewal RP: Analysis of the XRCCI gene as a modifier of the cerebral response in ischemic stroke. BMC Med Genet 2006, 7:78.

5. Huang Z, Huang PL, Panahian N, Dalkara T, Fishman MC, Moskowitz $M A:$ Effects of cerebral ischemia in mice deficient in neuronal nitric oxide synthase. Science 1994, 265:|883-|885.

6. Harper AJ: Production of transgenic and mutant mouse models. Methods Mol Med 2005, 104:185-202.

7. Lovblad KO, Baird AE, Schlaug G, Benfield A, Siewert B, Voetsch B, et al.: Ischemic lesion volumes in acute stroke by diffusionweighted magnetic resonance imaging correlate with clinical outcome. Ann Neurol 1997, 42(2): I64-I70.

8. Baird AE, Dambrosia J, Janket S, Eichbaum Q, Chaves C, Silver B, Barber PA, Parsons M, Darby D, Davis S, Caplan LR, Edelman RE, Warach $\mathrm{S}$ : A three-item scale for the early prediction of stroke recovery. Lancet 200I, 357(9274):2095-9.

9. De Keyser J, Sulter G, Luiten PG: Clinical trials with neuroprotective drugs in acute ischaemic stroke: are we doing the right thing? Trends Neurosci 1999, 22(I 2):535-540.

10. Morita-Fujimura Y, Fujimura M, Yoshimoto T, Chan PH: Superoxide during reperfusion contributes to caspase-8 expression and apoptosis after transient focal stroke. Stroke 200I, 32(10):2356-6I.

II. McCord JM: Oxygen-derived free radicals in postischemic tissue injury. N Engl J Med 1985, 3 I 2(3):159-63.

12. Liu PK: DNA damage and repair in the brain after cerebral ischemia. Curr Top Med Chem 200I, I(6):483-95.

13. Sugawara $\mathrm{T}$, Chan $\mathrm{PH}$ : Reactive oxygen radicals and pathogenesis of neuronal death after cerebral ischemia. Antioxid Redox Signal 2003, 5(5):597-607.

14. Gursoy-Ozdemir Y, Can A, Dalkara T: Reperfusion-induced oxidative/nitrative injury to neurovascular unit after focal cerebral ischemia. Stroke 2004, 35(6): 1449-53.

15. Frosst P, Blom HJ, Milos R, Goyette P, Sheppard CA, Matthews RG, Boers G], den Heijer M, Kluijtmans LA, Heuvel LP van den, et al.: A candidate genetic risk factor for vascular disease: a common mutation in methylenetetrahydrofolate reductase. Nat Genet 1995, I0(I):III-3.
16. Kang SS, Zhou J, Wong PW, Kowalisyn J, Strokosch G: Intermediate homocysteinemia: a thermolabile variant of methylenetetrahydrofolate reductase. Am J Hum Genet I988, 43(4):4I I-2I.

17. Choi BO, Kim NK, Kim SH, Kang MS, Lee S, Ahn JY, Kim OJ, Kim S, Oh D: Homozygous C677T mutation in the MTHFR gene as an independent risk factor for multiple small-artery occlusions. Thromb Res 2003, I I I(I-2):39-44.

18. Sacco RL, Anand K, Lee HS, Boden-Albala B, Stabler S, Allen R, Paik MC: Homocysteine and the risk of ischemic stroke in a triethnic cohort: the NOrthern MAnhattan Study. Stroke 2004, 35(10):2263-9.

19. Endres M, Ahmadi M, Kruman I, Biniszkiewicz D, Meisel A, Gertz K: Folate deficiency increases postischemic brain injury. Stroke 2005, 36(2):32I-5.

20. Dulhunty A, Gage P, Curtis S, Chelvanayagam G, Board P: The glutathione transferase structural family includes a nuclear chloride channel and a ryanodine receptor calcium release channel modulator. J Biol Chem 200I, 276(5):3319-23.

21. Laliberte RE, Perregaux DG, Hoth LR, Rosner PJ, Jordan CK, Peese KM, Eggler JF, Dombroski MA, Geoghegan KF, Gabel CA: Glutathione s-transferase omega $I-I$ is a target of cytokine release inhibitory drugs and may be responsible for their effect on interleukin-I beta posttranslational processing. I Biol Chem 2003, 278(19): 16567-78.

22. Kolsch $H$, Linnebank M, Lutjohann D, Jessen F, Wullner $U$, Harbrecht $U$, Thelen KM, Kreis M, Hentschel F, Schulz A, von Bergmann K, Maier W, Heun R: Polymorphisms in glutathione S-transferase omega-I and AD, vascular dementia, and stroke. Neurology 2004, 63(I 2):2255-60

23. Tanaka-Kagawa T, Jinno H, Hasegawa T, Makino Y, Seko Y, Hanioka $\mathrm{N}$, Ando M: Functional characterization of two variant human GSTO I-Is (Ala I 40Asp and Thr2 I7Asn). Biochem Biophys Res Commun 2003, 30I(2):5 I6-20.

24. Adams HP Jr, Bendixen BH, Kappelle LJ, Biller J, Love BB, Gordon DL, Marsh EE 3rd: Classification of subtype of acute ischemic stroke. Definitions for use in a multicenter clinical trial. TOAST. Trial of Org 10172 in Acute Stroke Treatment. Stroke 1993, 24(1):35-41.

25. Kissela B, Broderick J, Woo D, Kothari R, Miller R, Khoury J, et al.: Greater Cincinnati/Northern Kentucky Stroke Study: volume of first-ever ischemic stroke among blacks in a population-based study. Stroke 200I, 32(6): | 285-|290.

\section{Pre-publication history}

The pre-publication history for this paper can be accessed here:

http://www.biomedcentral.com/1471-2377/9/37/prepub

Publish with Bio Med Central and every scientist can read your work free of charge

"BioMed Central will be the most significant development for disseminating the results of biomedical research in our lifetime."

Sir Paul Nurse, Cancer Research UK

Your research papers will be:

- available free of charge to the entire biomedical community

- peer reviewed and published immediately upon acceptance

- cited in PubMed and archived on PubMed Central

- yours - you keep the copyright

Submit your manuscript here:

http://www.biomedcentral.com/info/publishing_adv.asp 